\title{
What Professional Librarians Expect from Administrators: An Administrator's Response
}

\section{Brian Alley}

In this article the author suggests that in addition to a recognized need for excellence on the part of library administrators, the librarians in the organization have an equal responsibility for excellence in their support of the library and its mission. Numerous opportunities exist for improving the lot of administrators and librarians through changes in library organization that allow for greater participation in the management process on the part of librarians, with increased opportunities to build trust and understanding.

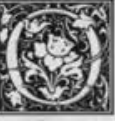

verall, I tend to agree with the author's suggestion that administrators should possess sufficient understanding, skill, and resources to provide the kinds of qualities discussed in the article. Nobody can argue that the list doesn't point to highly desirable attributes for any library administrator. The author suggests that the list of thirteen qualities may be a bit idealistic, and I quite agree. However, without questioning the value of these qualities I would suggest that there are a number of practical alternatives that ought to be considered, alternatives that I believe have the potential to correct some of the deficiencies existing in the traditional library organization and contributing to misunderstandings between librarians and administrators.

\section{JOB FACTORS}

The term qualities bothers me a bit, and since the author also suggests job-related factors, I prefer the latter and will shorten it to factors. What are the factors involved in a sound library administration? Some are provided by the administrator in the form of personality traits, skills, management style, and other components of the per- sonal baggage we all assimilate over the years and carry with us from one position to the next. Other factors such as professional salaries, good working environment, and stability are in areas where the administrator can exert influence to varying degrees but, in doing so, must contend with a whole variety of outside forces that may have much more muscle in the influence department. The most concerned, sympathetic, and understanding administrators among us won't make much of an impact on salaries for librarians when those salaries are determined by state boards, legislative bodies, or collective bargaining. Certainly there are opportunities in each of these instances for some involvement but probably not to the point of effecting significant change. Others with more influence and control determine the framework within which the administrator must operate. Within a given library there may be a number of factors over which the administrator has little or no influence, and it is important for everyone on the staff to recognize it.

\section{ORGANIZATION LIMITATIONS}

Academic libraries have always favored the classic pyramid organization chart 


\section{"Our expectations simply don't mesh with reality ..."}

with the director at the top. Colleges and universities follow the same plan, so why should the library be different? Unfortunately the plan doesn't work very well, simply because we tend to place too much faith in the infallibility of the person at the top. We tend to expect the ultimate in reason, logic, and fair play from our college and university presidents, and when they consistently fail in one department or another we become upset. They've let us down. Rarely do we take time out to consider the nature of the job and the multitude of burdens it places on a single human being. Many presidents recognize their own limitations and delegate whenever and wherever possible. The library administrator, like the college president, must contend with a number of unrealistic expectations. In the traditional, topdown, authoritarian, academic library organization, the chief administrator has been set up as the authority, last word, facilitator, benefactor, and provider for the whole organization. That's the role many job descriptions present. If administrators actually attempt to be all things to all people, they are bound to run into serious trouble. We frequently overestimate the ability of our administrators to perform in areas where they have little or no real influence or authority. Our expectations simply don't mesh with reality, and yet that doesn't prevent us from voicing our displeasure on such subjects as low professional salaries.

\section{EXPECTATIONS VERSUS REALITY}

Libraries are made up of people, collections of materials, budgets, and physical plants to house them. The administrator's job is to deal with all of them successfully. That's what the job description says. In reality administrators will need to respond to demands of varying degrees of intensity that will determine what percentage of their time must be allocated to each area of concern. The bigger the organization, the more time they will be required to devote to people and budget problems; ultimately, the budget will win out in the battle for the administrator's time. The administrator who spends the bulk of the day embroiled in fiscal matters is going to have to delegate the other areas of concern to able assistants. Picking the assistants and determining when and what to delegate are clearly critical factors in the ultimate success or failure of that administrator. If the assistants turn out to be inept or ineffectual at carrying out their responsibilities, the administrator gets the blame. The administrator who has selected competent assistants can claim some of the credit when their efforts turn out to be successful.

\section{PROTECTIONIST THINKING}

On looking back at the thirteen jobrelated factors, I find that they seem to suggest a kind of protectionist attitude. It is like asking administrators to promise to perform all of their duties in an exemplary manner while, at the same time, keeping the barbarians on the other side of the wall so that the staff can do their work in relative peace and harmony. I'm not at all sure that was the author's intent, but it does seem to me to suggest a kind of protectionist attitude that I seriously doubt anybody, administrator or librarian, would really want. No single administrator can or should even attempt to operate on that scale. That calls for far more responsibility than anyone can reasonably be expected to handle, especially when the authority to go along with the responsibility is probably going to be absent for at least 50 percent of what the administrator is expected to deliver. Up to now we haven't talked about the library as a team effort: a total commitment to serving the library clientele and furthering the mission of the institution. That approach requires the involvement of the entire staff-cooperating and sharing in the successes as well as the failures. And that brings us to some thoughts about what administrators should expect from professional librarians. 


\section{DROPPING THE OTHER SHOE}

Selecting one element of an organization for special attention suggests that equal time ought to be given to turning the question around. What do administrators expect from professional librarians? I doubt that there are as many as thirteen factors that should be considered, and if there were that many, I'm not sure that most of us would agree on all of them. Certainly, job performance is a major consideration. It includes a number of other factors such as communication skills, professional skills, responsibility, career development, leadership qualities, motivation, and more. In most cases our jobs are what we make them. It is possible for a creative, motivated librarian to turn a position into an exciting, rewarding experience even when the book budget is suffering, the air conditioning is faulty, and the anticipated 8 percent salary increase turned out to be half that amount. If the administrator must be accountable for the thirteen factors outlined in the article, the librarians certainly have an equal responsibility to fulfill the list of duties and responsibilities in their position descriptions. And some of those duties and responsibilities may be just as difficult to carry out as those on the list the administrator is working with. How is a librarian expected to accomplish all these things and still be required to staff the reference desk umpteen hours a week? That's a familiar complaint, and it takes us right back to the expectations versus reality issue again.

"Getting librarians and administrators to view their respective roles realistically and work together constructively in a collegial, congenial, trusting partnership would seem to be the top priority."

This is a good time to stop and read some of the ads in a current issue of the Chronicle of Higher Education. Whether we advertise for an acquisitions librarian, a chief library administrator or a university president, we simply can't avoid the tendency to ask for more than most humans can reasonably be expected to deliver. We know it's true, but we do it anyway. If we need library administrators who will motivate, lead, support, and facilitate, then surely we need professional librarians who are creative, enthusiastic, dynamic, and determined performers. Getting librarians and administrators to view their respective roles realistically and work together constructively in a collegial, congenial, trusting partnership would seem to be the top priority.

\section{A MIDDLE GROUND}

Administrators need to find ways to share the administrative process in a way that will provide opportunities for librarians to get administrative experience. Call it training or career development, it involves more librarians in various aspects of the administrative process and provides them with experiences they wouldn't have gotten otherwise. These experiences ultimately result in a greater sense of appreciation and understanding of the administrative role. For example, the creation of an administrative cabinet will bring librarians into a consulting relationship with the administration that in time would provide them with a sense of having a piece of the action, having real involvement in the decision-making process. The administrator benefits from the thinking of several librarians who are actually participating in the administrative process: there is great potential for improved relationships and better understanding for all concerned. No, it doesn't mean that the organization has deteriorated into a library commune. It is merely a process for creating a more open situation in which trust, sharing, and consulting can contribute to solving some of the problems created by the top-down, organization chart pyramid, compartmentalization of tasks, and lack of contact between administrator and librarians. In this middle ground situation the need for elaborate, detailed job descriptions is diminished, and trust (hopefully, a team spirit) will emerge as mystery and misunder- 
standing are removed from administration. If this sounds a little too pat and Pollyannaish, remember the alternative: librarians and administrators pointing accusing fingers at one another. If nothing else, by getting together they'll have a much better chance of keeping the barbarians on the other side of the wall.

\section{CONCLUSION}

Without doubt librarians have every right to expect a certain level of performance from their administrators. But in a traditional, authoritarian organization, how do they go about getting their concerns across without creating misunderstanding and confrontation? By the same token, administrators are equally concerned about their expectations for the performance of professional librarians. Producing lists of factors suggests, to me at least, demands for performance standards or similar means of measuring performance. Rather than see librarians confronting administrators in a no-win situation, I suggest that the traditional, authoritative library administration bend a bit, allowing more participation in the administrative process in order to build trust and understanding, while at the same time establishing a more creative, democratic, and collegial atmosphere for dealing with library issues. 